\title{
Comparative Investigation of Persian's Cognates and False Friends with Some IE Languages
}

\author{
Mohammad R. Talebinejad \\ Islamic Azad University, Shahreza Branch, Iran \\ Email: rtalebinezhad@yahoo.com \\ Abolhassan Nazari Sarmazeh \\ Islamic Azad University, Shahreza Branch, Esfahan, Iran \\ Email: Abolhassan.nazari@gmail.com
}

\begin{abstract}
This study aims at identifying a kind of cognate words which are called false or true cognates in Persian and some IE Languages. False cognates are words which have the same form and pronunciation in two or more languages, but despite their similarity in form, and pronunciation they have dissimilar meanings in the two languages. True cognates are the result of kinship relations across languages, or borrowings. False and true cognates might be found in nearly all languages with any kind of relation to other languages. There are still some "real" cognates found in the lexicon of Persian and some IE languages. By document reviewing much interesting information has been revealed. The conclusions of this study will provide new insights into the linguistic and the communication problems derived from a misuse of these lexical items. The study of false friends and true Cognates has several implications for contrastive analysts, error analysts, translators, foreign language teachers and learners, curriculum designers, as well as lexicographers and lexicologists.
\end{abstract}

Index Terms — false friends, true cognate, IE languages, dissimilar meaning

\section{INTRODUCTION}

\section{A. The Place of Persian among the Families of Languages}

Persian is a member of the Indo-European family of languages. Indo-European is one of the most widely spoken and diverse families of languages in the world today. It includes, among others, the Romance languages (Spanish, French, Latin, etc.), the Slavic languages (Russian, Polish, etc.), the Germanic languages (English, German, Swedish, etc.), the Celtic languages, Baltic languages, Greek, Armenian, and Albanian. All of these languages, as well as some extinct languages like Tocharian and Illyrian, are thought to originate with a single prehistoric language called Proto-IndoEuropean, which was spoken between 3000 and 5000 years ago. The branch of Indo-European that Persian belongs to is known as the Indo-Iranian or Indo-Aryan branch. It includes both the Indic languages (Sanskrit, Hindi, Marathi, etc.) spoken in northern India today and the Iranian or (also called Aryan) languages. Persian is the most widely spoken of the Iranian languages today. Other modern-day Iranian languages include Pashto, which is spoken in much of Afghanistan; Tajik, spoken in Tajikistan; and Kurdish, which is spoken in the Kurdish regions of Turkey, Iraq, Iran, and Syria. There are also several Iranian languages spoken by certain tribes in Iran such as Luri, Baluchi, and Tat. In the past, there were other Iranian languages such as Avestan, the language of the Avesta, a sacred text of the Zoroastrian religion, which was the dominant religion in Iran before the Islamic conquest. Persian has undergone many changes in the past two millennia, the most significant of which has most certainly been the influence of Arabic since the Islamic conquest of Persia in the year 650. Over the years, Persian has borrowed up to half of its vocabulary from Arabic as well as certain grammatical elements. This impact of Arabic is profound not only because of its magnitude but because the sounds and syntax of Arabic, a Semitic language, are so different than those of Persian. Since the Middle Ages, Persian has been written in a modified form of the Arabic alphabet, although in pre-Islamic times it was written in an older alphabet known as Pahlavi.

Words are the elements of a language used to identify objects, ideas and express feelings. These words are also the mirrors in that they are a reflection of the cultural history and development of a people. Tracing words to their origins will open a new window to human civizilition and culture and help us understand the roots of some of our present social trends and attitudes. It is likely to consider as vital characteristic for teachers to be aware of the misuse of learners to enhance communication and improve language learning, and find convenient solutions and recognize those misbehaviors to get efficient result. This study investigates that knowing the origin of learners' misbehaviors (as a result of using false friends) eradicate miscommunication in the process of language learning. Its effect should be examined based on learners' reflections. False friends have been widely considered in different language areas: translation studies, language teaching, lexicography or contrastive linguistics. Koessler and Derocquigny (1928) used the term faux amis in their well-known book Les Faux Amis, ou les Trahisons du Vocabulaire Anglais. Here is the source of this metaphor which is extensively used in language teaching all over the world. From an EFL context, a false friend could be defined 
as an L2 word that is formally similar to an L1 word in spelling and/or pronunciation but whose meanings are totally or partially different in both languages false friends have become a real problem for language learners. This paper focuses on true friends and on their role in the interlanguage of Persian learners of other IE languages. The present study will optimistically offer teachers with some evidence of the student's use of these lexical items, which may be useful for their actual teaching in the classroom.

As a teacher it is often worth making a collection of false friends and true cognates you come across; this will help you discover potential problems in the classroom before they arise and also act as a study aid for your students. The same false friends tend to occur again and again and to try and avoid errors, they need to be dealt with individually and specifically with each class as they arise. It is sometimes useful to use the students' MT in the classroom to help explain the difference here; certainly you will need to make the students aware of what a false friend or true cognate word or phrase means in their own language and then in other IE languages. Once the false friend has been pointed out and noted by the students, you can create a set of exercises to check the meaning. For example by multiple-choice exercises, where the students must select the correct meaning of a phrase or they must choose the correct synonym. By looking at what the students do here you can see if they need more work and practice in learning the meaning of specific English words which are false friends to their MT. False cognates are pairs of words in the same or different languages that are similar in form and meaning but have different roots. That is, they appear to be, or are sometimes considered, cognates, when in fact they are not. Even if false cognates lack a common root, there may still be an indirect connection between them.

\section{B. Statement of Problem}

Teachers, linguists and psycholinguists have always been interested in errors produced by second language learners, either in their speech or writing or both. In fact learners' errors have been the subject of extensive investigation and heated controversy for quite a long time.

Surveys on the false friendship phenomenon are rather scarce (Chacón, 2006).Studies show that almost all language users of IE languages are bored and confused in comprehending those languages which share common features inversely. Moreover, they are less likely to learn. For increasing learner engagement and deeply understanding of materials it is better to eradicate the sources of miscomprehension. There might be also false friends in two or many IE languages that make the comprehension doubly difficult. The learner may assume that since the source and target language have the same form, they can also have the same meaning or stylistic features.

\section{Purpose and Scope of Study}

The discussion of false and true cognates has a lot of pedagogical implications for error analyst and foreign and second language learners. Moreover, errors can form good distracters for test constructors, especially in multiple choice items.

The purpose of the study was to recognize and then enumerate the false friends and true cognates of IE language. Specifically, it aims to reveal miscommunication between interlocutors. The key research inquiries are: 1) what are the Persian true cognates with comparison to some IE languages? 2) How these true cognates and false friends effect communication?

\section{Significance of Study}

\section{Significance of false cognates}

Keshavarz (2007) refers to this type of errors as inaccurate use of a target language word because of its phonological similarities with a word in the learner's mother language; similarity in appearance and not in meaning. This kind of deceptive cognate has been referred to by some as 'false freind' (Newmark, 1988).

Example:

- My father bought a new machine last week.

The word machine in this sentence is used because of the influence of its cognate /machine/ 'car' in Persian.

Similarly the word 'cigar' in the following sentence has been used because of its superficial similarity with the word /sigar/ in Persian.

Persian is the most important of a group of several related languages that linguists classify as Indo-Iranian. Persian speakers regard their language as extremely beautiful, and they take great pleasure in listening to the verses of medieval poets such as Ferdowsi, Hafez, and Sadi. The language is a living link with the past and has been important in binding the nation together. It is the language of government and public instruction and is the mother tongue of half of the population. Persian is spoken as a second language by a large proportion of the rest. As part of the Indo-European family of languages, Persian is distantly related to Latin, Greek, the Slavic and Teutonic languages, and English. This relationship can be seen in such cognates as beradar (brother), pedar (father), and mader (mother). It is a relatively easy language for English-speaking people to learn compared with any other major language of the Middle East. Verbs tend to be regular, nouns lack gender and case distinction, prepositions are much used, noun plural formation tends to be regular, and word order is important. The difficulty of the language lies in the subtlety and variety of word meanings according to context. Persian is written right to left in the Arabic script with several modifications. 
Among educated Persians, there have been sporadic efforts as far back as the tenth century to diminish the use of Arabic loanwords in their language. Both Pahlavi shahs supported such efforts in the twentieth century. During the reign of Reza Shah Pahlavi (1925-41), serious consideration was given to the possibility of Romanizing the writing of Persian as had been done with Turkish, but these plans were abandoned. Since the Revolution, a contrary tendency to increase the use of Arabic words in both spoken and written Persian has emerged among government leaders. So as a member of a group of several related languages that linguists classify as Indo-European languages it is important to consider the true cognates and false friends of Persian language in order that other language users become aware of such issues. From the point of view of language teaching, the misuse of false friends has two types of "side effects". On the one hand, it reveals the students' incomplete lexical competence and, on the other hand, it leads to the communication of unintentional meanings. These reasons clearly give good reason for the need for discussing and identifying these problems in order to alleviate them.

\section{E. Definition of Key Terms}

\section{False cognates as Interlingual errors}

Interlingual errors result from the transfer of phonological, morphological, grammatical, lexico - semantic and stylistic elements of the learners' mother tongue to the learning of the target language. As we noticed above false cognates are as a result of Interlanguage as a source of error, hence for the cases of mother tongue interference false cognates occur.

Cognate (Latin: cognatus co+gnatus, ie. nasci "to be born") means: "related by blood, having a common ancestor, or related by an analogous nature, character, or function" (Wikipedia). The clearest cases are those where the parent language is known to exist. For example, on the basis of the various words for father in the Romance languages, such as père and padre, it is possible to work out how they all derived from the Latin word pater. If Latin no longer existed, it would be possible to reconstruct a great deal of its form, by comparing large numbers of words in this way. A word that is related in origin to another word, such as English brother and German Bruder. In linguistics, cognates are words in one or more languages that have a common origin, meaning that they are descendents of a same word, possibly in a common predecessor language. One example is the English word night, whose cognates include words with the same meaning in other languages, like nuit (French), Nacht (German), and nakti- (Sanskrit). In less formal usage, "cognate" may simply mean a synonymous relationship between words.

Cognates need not have the same meaning: dish (English) and Tisch ("table", German), or starve (English) and sterben ("die", German), or head (English) and chef ("chief, head", French), serve as examples as to how cognate terms may diverge in meaning as languages develop separately, eventually becoming false friends. Cognates may also arise through borrowings into languages. So the resemblance between English to pay and French payer originates through English borrowing to pay from Norman which, like French, had derived its word from Gallo-Romance.

Examples of cognates in Indo-European languages are the words night (English), nuit (French), Nacht (German), nacht (Dutch), nicht (Scots), nat (Danish) noc (Czech, Polish), noch (Russian), noć (Serbian), nox (Latin), nakti(Sanskrit), natë (Albanian), noche (Spanish), nos (Welsh), noite (Portuguese), notte (Italian), nit (Catalan), noapte (Romanian), nótt (Icelandic) and naktis (Lithuanian), all meaning night and all deriving from Proto-Indo-European (PIE) *nekwt-, "night."

Another Indo-European example is star (English), setare (Persian), str (Sanskrit), étoile (French) star (Sinhala), aster (Greek), stella (Latin, Italian), estrella (Spanish), stea (Romanian and Venetian), stairno (Gothic), Stern (German), ster (Dutch and Afrikaans), starn (Scots), stjerne (Norwegian), stjarna (Icelandic), , seren (Welsh), steren (Cornish), estel (Catalan), estrella (Spanish), estrela (Portuguese) and estêre (Kurdish), from PIE *ster-, "star".

The similarity of words between languages is not enough to demonstrate that the words are related to each other, in much the same way that facial resemblance does not determine whether two people are genetically related. Over the course of hundreds and thousands of years, words may change their sound completely. Thus, for example, English five and Sanskrit pança are cognates, while English over and Hebrew a'var are not, and neither are English dog and Mbabaram dog.

\section{METHOD}

One of the common difficulties in understanding the linguistic system of language learners is the fact that such systems cannot be directly observed. They must be inferred by means of analyzing production and comprehension data. In general, it is easier to detect productive errors; that is, errors which occur in the speech or writing of second language learners as opposed to errors in the receptive skills: reading and listening comprehension. This is because productive linguistic behavior is easily recordable; whereas, receptive most often has no observable behavioral concomitants.

\section{A. Research Design}

Being conducted to compare the cognate's component of Persian and some IE languages, this research has been completed through document reviewing, one of qualitative research methods. Data has been analyzed through descriptive analysis. 
Case study was made use of in this study. Different articles comparing special cognates or false friends were scrutinized based on some predetermined factors. Finally, those words which were regarding true or false friends were enumerated that is a qualitative study.

\section{B. Data Collection, Data Analysis}

Having adequate data is essential for any error analysis. The choice of appropriate procedures for collecting data is, in fact, one of the crucial steps in the investigation of the learner's language. In some cases, learners' utterances might be ambiguous; that is, more than one plausible interpretation is possible. This obviously presents a problem of interpretation and linguistic description. Corder (1973) suggests that such ambiguous utterances should set aside.

Typical case sampling - one of purposeful sampling techniques - was employed during the recognition of the research sample. Yildirim and $\operatorname{Simsek}(2005)$ says typical case sampling is generally used to introduce a new application or to work on new things within a series of cases by determining the most typical ones and analyzing them. Reviewing different scholarly articles in various languages written in English used in this research were found to be comprehensive enough in terms of reflecting the case conceptually.

Data was collected through document reviewing, one of qualitative research methods. Document reviewing includes examining written materials that bear information regarding the issue to be investigated (Yildirim and Simsek, 2005). Providing real, easily accessible and available data, documents are used to figure out solutions to problems by researchers. The word 'document' is used as an umbrella term that covers all written and visual materials. Three types of documents are as follows: public documents, personal documents, and physical materials. Since it is not applicable to observe speakers of different IE languages, public and personal documents were utilized.

Descriptive analyses have been employed during the analysis and interpretation of the data. Descriptive analysis includes decoding of the data, developing a coding key, coding the data onto the key, classifying the data in terms of emerging thematic frames, identifying the findings, and interpreting those findings (Yildrim and Simsek, 2004, p. 171). Direct quotation was used during presentation of the findings.

\section{Findings and Interpretation}

In accordance with the research questions, findings are presented in two categories as what are the Persian true cognates or false friends with other IE languages and how they affect the process of communication.

\section{Findings regarding Persian true cognates with some IE languages}


TABLE 1

DISPLAYS THE FINDINGS RELATED TO THE FIRST RESEARCH QUESTION

\begin{tabular}{|c|c|}
\hline$==$ English $==$ & $==$ Persian $==$ \\
\hline bad & bad \\
\hline band & band (it's present stem of bastan: to close) \\
\hline brother & barâdar \\
\hline cow & gâv \\
\hline daughter & dokhtar \\
\hline door & dar \\
\hline father & pedar \\
\hline God & Khodâ \\
\hline lip & lab \\
\hline mother & mâdar \\
\hline name & nâm \\
\hline new & now \\
\hline right & râst \\
\hline star & setâre \\
\hline stone & sotun (pillar) \\
\hline thou & to \\
\hline jungle & jangal \\
\hline pyjamas & pây-jâma \\
\hline attack & pâtak \\
\hline balcony & bâlâkhâne \\
\hline$==$ French $==$ & $==$ Persian $==$ \\
\hline dent & dandân \\
\hline deux & do \\
\hline donner & dâdan \\
\hline genou & zânu \\
\hline mourir & mordan \\
\hline que & $\mathrm{ke}$ \\
\hline qui & ki \\
\hline tu & to \\
\hline$==$ German $==$ & $==$ Persian $==$ \\
\hline Bruder & barâdar \\
\hline Gott & Khodâ \\
\hline Mutter & mâdar \\
\hline neu & now \\
\hline nun & aknun (it has been also nun in Middle Persian) \\
\hline Tochter & dokhtar \\
\hline Tür & door \\
\hline Vater & pedar \\
\hline du & to \\
\hline$==$ Spanish $==$ & $==$ Persian $==$ \\
\hline tú & tu (You) \\
\hline para & bara (for) \\
\hline naranja & narenj (orange) \\
\hline vale & baley (OK!) \\
\hline papá & baba (dad/father) \\
\hline pijama & OF PERSIAN ORIGIN \\
\hline NARANJA & OF PERSIAN ORIGIN \\
\hline
\end{tabular}

As can be seen in Table 1, Persian shares many cognates with other IE languages. Of course some points should be bear in mind. For instance, some believe the word "bad" is just a coincidence with bad in English language, and their origins are different. Some more amazingly close cognates between Persian and English are:

better=behtar, $\mathrm{road} / \mathrm{rue}=\mathrm{rah}, \mathrm{me} / \mathrm{moi}=$ man, foreign $=$ farang

"Foreign" and "farang" are not cognates, they're false friends. The Persian word is not related; "farang" or "farangi" is derived from the Persian "farânk," which refers to the Franks who dominated Western Europe for centuries.

para --> bara (for): regarding to Spanish and Persian comparison ,Persian barâ is actually a compound: ba+râ; just like cherâ/chirâ (chi+râ) and zirâ (az+i+râ). Less people know this. Though, we cannot claim that Persian barâ and Spanish para are exact cognate.

2. More comprehensive review of Persian true cognates with some IE languages 


\begin{tabular}{|c|c|c|c|c|c|c|c|c|c|}
\hline English & Persian & Spanish & French & Italian & German & Hindi & Dutch & Swedish & lithuanian \\
\hline KISS & boosse & beso & baiser & bacio & & & & & bucinys \\
\hline THUNDER & tondar & & & & donner & & & & \\
\hline KNEE & zanu & & genou & & & janu & & & \\
\hline BREAST & sineh & & sein & seno & & & & & \\
\hline CRY & geryeh & & cri & & schrei & & & grata & \\
\hline SHAME & sharm & & & & scham & & & scam & \\
\hline TYPHOON & toophan & & & & & & & & \\
\hline THROAT & galoo & & & gola & & gela & & & \\
\hline BALD & kal & calvo & & calvo & kahl & & kaal & & \\
\hline CORPSE & lasheh & & & & leiche & lash & & & \\
\hline ON FOOT & piadeh & & a pied & a piedi & & & & & \\
\hline ENOUGH & bass & basta & & basta & & & & & \\
\hline GOOSE & ghaaz & ganso & & & & & & gas & \\
\hline THAT & $\mathrm{ke}$ & & que & che & & $\mathrm{ki}$ & & & \\
\hline DEAD & mordeh & & mort & morto & & & & & \\
\hline JACKAL & shaghal & & chacal & sciacallo & & & & schakal & \\
\hline WHO & $\mathrm{ki}$ & & qui & che & & & & & \\
\hline WHAT & $\begin{array}{l}\text { che or che } \\
\text { chizi }\end{array}$ & & & che cosa & & & & & \\
\hline MOTHER & madar & madre & mere & madre & & & & mor & \\
\hline FATHER & pedar & & & padre & vater & & vader & & \\
\hline DAUGHTER & dokhtar & & & & tochter & & dochter & & \\
\hline TOOTH & dandan & & & & & & & & dantis \\
\hline TWO & do & dos & deux & duo & & do & & & $\mathrm{du}$ \\
\hline FIVE & panj & & & & & panch & & & \\
\hline EIGHT & hasht & & & & acht & aat & & & \\
\hline NINE & noh & & neuf & nove & neun & no & & nio & \\
\hline PONDER & pendar & & & & & & & & \\
\hline INTER & andar & & & & unter & & onder & & \\
\hline STAR & setareh & & & stella & stern & & ster & & \\
\hline IS & ast & es & est & & ist & & & & \\
\hline NOT & nist & & & & nicht & & & & \\
\hline MOUSE & mush & & & $\begin{array}{l}\text { mouse } \\
- \text { ze }\end{array}$ & & & muis & & \\
\hline CHIN & chaaneh & & & & & & & & \\
\hline DOOR & dar & & & & & & deur & & \\
\hline STAND & istadan & & & & & & & & stendas \\
\hline NAVEL & naf & & & & nabel & & & & \\
\hline
\end{tabular}

\section{Findings regarding Persian false friends with English language}

\begin{tabular}{|c|c|}
\hline English & Persian \\
\hline Man= male person & Man= I( subject pronoun) \\
\hline Sad= unhappy & $\begin{array}{l}\text { Sad= dam; a barrier that is built across a river in order to stop the } \\
\text { water from flowing }\end{array}$ \\
\hline Come & Cam $=$ palate, mouth, mortise \\
\hline No & $\mathrm{No}=$ new \\
\hline $\mathbf{B e}$ & $\mathrm{Be}=$ without \\
\hline fan & Fan $=$ art, technique, trick \\
\hline Run & Ran $=$ thigh \\
\hline Foot $=$ a member of body & Foot = puff, blow; to blow out \\
\hline Cat $=$ an animal & Cat $=$ a part of body. shoulder $(-$ blade $)$ \\
\hline $\begin{array}{l}\text { Rust }=\text { a redish-brown substance that is formed on some } \\
\text { metals by the action of water and air. }\end{array}$ & Rast $=$ straight, right \\
\hline Lot $=$ many & Lot $=$ naked \\
\hline Tan $=$ yellowish brown in color & Tan = body, person \\
\hline call & $\mathrm{Cal}=$ unripe, green \\
\hline
\end{tabular}

As it is mentioned above false friends have the same pronunciation and form but different meaning, so in order to eradicate or alleviate misunderstanding and miscommunication between English and Persian interlocutors it is essential to be aware of false friends. The misuse of lexical may lower the mutual communication, and on the other hand by the well use of lexical no misunderstanding occurs.

All of us miscommunicate at times. Reasons for it vary from each person and situation. But a few wrong presumptions that we make about communication hamper our prospects in the long-term. As an interlocutor with another language it is beneficial to be conscious of different facilitating and debilitating words that are fruitful and harmful respectively. By facilitating we mean those words which are true cognate and facilitate the process of 
communication, and by debilitating we mean those words which minimize mutual communication and hamper meaning. Hence for knowing true cognates and false friends might pave the way for better understanding. One of the indexes of true understanding is being aware of cognates and especially false friends. So it is vital for a second or foreign language learner to identify, know, and enumerate those impeding false friends and facilitating cognates. This will help you discover possible problems in the classroom before they arise and also act as a study aid for interlocutors.

\section{RESULTS, CONCLUSIONS, AND IMPLICATIONS}

In this implementation, major findings of the study were considered as the interlocutors' chances for identifying, learning and eradicating sources of false friends, and miscommunications. Cognates were also considered as facilitating communication. As a whole, a major challenge facing all interlocutors is how to determine why or what causes interlocutors to be unusual or abnormal. The next major challenge is managing, handling, or controlling of two interlocutor's miscommunication problems. We know that when false friends get out of control, communication is negatively impacted, and in the other hand with the familiarity of true cognates, no troublesome occurs in the process of communication among speakers of different root related( that is)IE languages. In other words, being aware of the true cognates or false friends, communication and learning are facilitated. As suggested by the current study, students' problems with false friends could be greatly reduced if teachers paid more attention to a meaningful teaching of these lexical items. One way of doing this is by teaching false friends in context. The use of audiovisual materials (pictures, videos, cartoons) in the classroom might be valuable and could promote students' reflection on the potential misunderstandings caused by those problematic words in naturally occurring situations. To summarize, this study shows that there is room for teachers' action in relation to false friends. EFL learners have serious problems when using these lexical items and teachers should deal with this issue so that learners' lexical competence expands and potential misunderstandings can be prohibited. Students' errors in the realm of false and true cognates have always been of interest and significance to teachers, syllabus designers and test developers. It is widely held that insight gained from the study of learners' errors can provide invaluable information for devising appropriate materials and effective teaching techniques, and constructing tests suitable for different groups of learners at various stages of second language development. Accordingly this study offers much fruitful contribution to different field of study. The study of false friends and true Cognates has several pedagogical implications for contrastive analysts, error analysts, translators, foreign language teachers and learners, curriculum designers, as well as lexicographers and lexicologists.

\section{A. Implication for Teachers}

Teachers can benefit from the findings of false or true cognates in different ways. They can have an identified and classified category to deal with and to devise suitable materials and teaching techniques. This study will enable the teacher to emphasize more those areas where the error frequency is higher. This study enables teachers to focus on controversial issues and devote more time to the items they have been working on.

\section{B. Implication for Learners}

From the study of false or true cognates learners can identify the problematic areas for themselves at different level of instruction. They will be able to infer the nature of native and target language in their learning career and discover what they still have to learn.

\section{Implication for Syllabus Designers}

These kind of lexical errors are significance to syllabus designers to see what item are crucial to be included in the syllabus and what are redundant and should be excluded. They can provide serve remedial courses and program.

\section{REFERENCES}

[1] Benjamin, W. (2004). Indo-European Language and Culture. Blackwell Publishing.

[2] Corder, S. Pit (1973). Introducing Applied linguistics. Harmondsworth: Penguin.

[3] Chacón Beltrán, R. (2006). Towards a Typological Classification of False Friends (Spanish- English). Revista Española de Lingüística Aplicada 19 (pp. 29-39).

[4] Keshavarz, M. H. (2007). Contrastive Analysis and Error Analysis. Tehran: Rahnama Press.

[5] Koessler, M., \& Derocquigny, J. (1928). Les Faux Amis ou les Trahisons du Vocabulair Anglais. Paris: Librairie Vuibert.

[6] Newmark, P. (1988). A Textbook of translation. London: prentice Hall international Inc.

[7] Sevan, N. (2007). Etymological Dictionary of Modern Turkish. Adam Y. Istanbul.

[8] Parkes. G. \& Cornell. A. (1992), 'NTC's Dictionary of German False Cognates', National Textbook Company, NTC Publishing Group.

[9] Yildrim, A. \& simsek, H. (2005). Sosyal bilimlerde nitel aratrma yöntemleri. (5. Bas m). Ankara: Seçkin Yay nc 1 k.

[10] Wikipedia, the free encyclopedia, retrieved February 5, 2012, from: http://en.wikipedia.org/wiki/False_cognate 


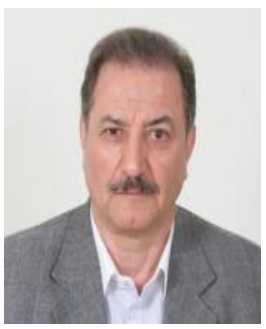

Mohammad R. Talebinejad is an Associate Professor of Applied Linguistics at Islamic Azad University, Shahreza Branch. He is also an associate faculty member at Sheikhbahaee University, Iran.

Dr Talebinejad received his BA in English Language and Literature, University of Isfahan in 1975. He then got his MA in TEFL from the University of Texas at Austin, USA in 1977. For his doctoral degree, Dr Talebinejad was admitted to the University of Sheffield, UK, where he did his PhD in Applied Linguistics in 1994.

He has widely published in Iranian as well as International professional journals such as Metaphor and Symbol, English Teaching Forum, Language Testing, IJAl, Language and Translation, Journal of Social Sciences, The International Journal of Humanities, and other local and international journals. Dr Talebinejad has presented papers in International conferences such as AILA, 2000; Atiner, 2011; RAAM, 2002, 2001 in Paris and Tunis, EUROSLA, Switzerland, 2006; Multicultural Conference, 2007, China. In addition, Dr Talebinejad has authored/coauthored eight books in related fields and ESP.

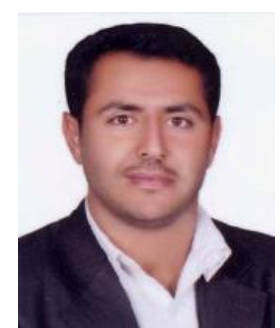

Abolhassan Nazari Sarmazeh was born in Sarmazeh, Chaharmahal and Bakhtiari, Iran (March 19, 1979).He wants to defend his MA theses in TEFL from the University of Islamic Azad University, Shahreza Branch, Esfahan, Iran. He received his B.A. in English teaching in 2008. He has been teaching English in different schools and language institutes since 2003. At the present time, he is trying to complete and publish the final edition of his book titled, who is a resourceful teacher. Mr Nazari is a member of Iran translator cyber association (ITCA). He is very interested in reading fresh articles related to his expertise in his free time, and eagerly wants to remove those demotivating, and impeding factors during teaching. 